УДК 373.3/5.091.12:005.336.5.044.337]:004.777

DOI: 10.37026/2520-6427-2021-108-4-24-30

\section{Ірина ІВАНЮК,}

кандидат педагогічних наук, старший науковий співробітник відділу компаративістики інформачійно-освітніх інновачій Інституту інформаційних технологій і засобів навчання НАПН України, м. Київ, Украӥна ORCID:0000-0003-2381-785X, e-mail:irinaivanyuk72@gmail.com

\section{Оксана ОВЧАРУК,}

кандидат педагогічних наук, старший науковий співробітник, завідувач відділу компаративістики інформачійно-освітніх інновачій Інституту інформаційних технологій i засобів навчання НАПН України, м. Київ, Україна ORCID: 0000-0001-7634-7922, e-mail:oks.ovch@hotmail.com

\section{Іван ВСТРОВ,}

проректор із зовнішніх зв'язків i моніторингу якості освіти Рівненського обласного інституту післядипломної педагогічної освіти, старший викладач кафедри природничо-математичної освіти, м. Рівне, Украӥна ORCID: 0000-0002-6000-3102, e-mail:vyetrov@ukr.net

\title{
ВИКОРИСТАННЯ ІНСТРУМЕНТІВ I РЕСУРСІВ ЦИФРОВОГО ОСВІТНЬОГО СЕРЕДОВИЩА ДЛЯ ЗДІЙСНЕННЯ ДИСТАНЦІЙНОГО НАВЧАННЯ У ЗАКЛАДАХ ЗАГАЛЬНОЇ СЕРЕДНЬОЇ ОСВІТИ: РЕЗУЛЬТАТИ ДОСЛІДЖЕНЬ
}

\begin{abstract}
Анотація. У статті розкрито питання використання інструментів і ресурсів циифрового освітнього середовища для здійснення дистанційного навчання у закладах загальної середньої освіти на прикладі опитувань педагогів у період карантину. Особливістю представленого матеріалу є те, щз він є результатом опитувань, проведених у 2021 рочі на двох рівнях: всеукраїнському та обласному, а також на порівнянні отриманих відповідей респондентів (1463 особи). Виявлені проблеми пов'язані переважно з неналежним оснаменням закладів загальної середньої освіти, вчителів та школярів зокрема необхідним обладнанням та складнощами з доступом до швидкісного інтернет-зв 'язку, недостатньою підготовленістю вчителів до використання засобів та інструментів інформаційно-комп'ютерних технологій, відсутністю швидких
\end{abstract}

консультацій учителів щчодо використання засобів дистаниійного навчання та ін. Порівняння результатів дозволили виявити відповідні тенденції існуючих проблем, вказаних вище, та надати рекомендаиії органам влади, закладам освіти, організаціям громадянського суспільства та іншим зацікавленим сторонам щзодо вирішення питань підтримки вчителів у здійсненні дистаниійного навчання. Новизна дослідження полягає у створенні та використанні інструментарію опитування педагогічних працівників на різних рівнях прийняття рішень та їх порівнянні з метою виокремлення нагальних проблем.

Ключові слова: інформачійно-освітнє середовище, ичифрові інструменти, педагоги, дистаниійне навчання, інформаційно-комп 'ютерні технології, COVID-19. 
Iryna IVANYUK,

Candidate of Pedagogical Sciences,

Senior Research Fellow,

Department of Comparative Studies

of Information and Educational Innovations,

Institute of Information Technologies and Learning Tools of National Academy of Educational Sciences of Ukraine, Kyiv, Ukraine

ORCID: 0000-0003-2381-785X,

e-mail:irinaivanyuk72@gmail.com

Oksana OVCHARUK,

Candidate of Pedagogical Sciences,

Senior Research Fellow,

Head of the Department of Comparative Studies

of Information and Educational Innovations,

Institute of Information Technologies and Learning Tools of National Academy of Educational Sciences of Ukraine, Kyiv, Ukraine

ORCID: 0000-0001-7634-7922,

e-mail:oks.ovch@hotmail.com

Ivan VETROV,

Vice-Rector for External Relations and Education Quality Monitoring,

Rivne Regional Institute

of Postgraduate Pedagogical Education,

Senior lecturer at the Department

of Natural and Mathematical Education,

Rivne, Ukraine

ORCID: 0000-0002-6000-3102,

e-mail:vyetrov@ukr.net

\section{USE OF DIGITAL EDUCATIONAL ENVIRONMENT TOOLS AND RESOURCES FOR DISTANCE LEARNING IN SECONDARY EDUCATION INSTITUTIONS: STUDY RESULTS}

\begin{abstract}
The article reveals the use of tools and resources of the digital educational environment for distance learning in general secondary education institutions on the example of surveys of teachers during the quarantine period. The peculiarity of the presented material is that it is the result of surveys conducted in 2021 at two levels: all-Ukrainian and regional, as well as a comparison of the answers received by respondents (1463 people). The identified problems are mainly related to inadequate equipment of secondary schools, teachers and families with the necessary equipment and difficulties with access to high-speed Internet connection, insufficient readiness of teachers to use ICT tools and instruments, lack of quick consultations of teachers on the use of distance learning tools.

The comparisons of the results revealed the trends of the existing problems mentioned above and provided recommendations to the authorities, educational institutions, civil society organizations and other stakeholders on how to support teachers in the implementation of distance learning. The novelty of the study is the creation and use of tools for interviewing teachers at different levels of decision-making and comparing them to identify pressing issues.
\end{abstract}

The all-Ukrainian survey was conducted in the period from January 10, 2021 up to March 10, 2021 by the Department of Comparative Studies and Information and Educational Innovations of the Institute of Information Technologies and Teaching Aids of the National Academy of Pedagogical Sciences of Ukraine. The regional survey was conducted in the period from 01 up to 20 April 2021 by Rivne Regional Institute of Postgraduate Pedagogical Education. Based on two surveys, the article presents comparative tables on the use of ICT tools for distance learning, and presents proposals for Ukrainian stakeholders.

Key words: information and educational environment, digital tools, teachers, distance learning, ICT, COVID-19.

Постановка проблеми. У зв'язку з уведенням карантинних заходів упродовж 2020-2021 н. р. перед українською системою освіти нагально постали питання організації дистанційного навчання у закладах загальної середньої освіти (далі - 33СO), що передбачає залучення до цього процесу всіх зацікавлених сторін: учителів, керівників закладів освіти, учнів, батьків, державних і місцевих органів влади. Проблема 
створення умов та забезпечення організації дистанційного навчання школярів постала як в Україні, так і в усьому світі при запровадженні карантинних заходів у зв'язку з поширенням COVID-19 (OECD, 2020; Council of Europe, 2020).

Учені відділу компаративістики інформаційноосвітніх інновацій Інституту інформаційних технологій і засобів навчання НАПН України у січні 2021 року провели дослідження серед педагогічних працівників iз різних областей країни шляхом онлайн-анкетування (Іванюк, Овчарук, 2021). Передумовою для його проведення було опитування, здійснене навесні 2020 року, що висвітлювало проблеми та потреби вчителів у здійсненні дистанційного / змішаного навчання у З3СО під час упровадження першого карантину, спричиненого пандемією COVID-19 (Іванюк, Овчарук, 2020; Ivaniuk, Ovcharuk, 2020). Метою онлайнопитування була реалізація таких завдань: виявлення громадської думки педагогічних працівників закладів загальної середньої освіти щодо проблем і потреб, що виникають під час упровадження дистанційного та змішаного навчання в умовах карантину; визначення ступеня готовності педагогічних працівників використовувати онлайн-інструменти та онлайнресурси під час здійснення дистанційного та змішаного навчання в умовах карантину; порівняння результатів опитування 2021 року щодо використання онлайн-засобів та онлайн-ресурсів із результатами першого опитування навесні 2020 року; визначення рівня цифрової компетентності педагогічних працівників шляхом самооцінювання на основі Рамки цифрової компетентності для громадян; надання відповідних рекомендацій зацікавленим сторонам на основі оцінки стану ситуації, що склалася під час карантину.

Взявши за основу зазначену вище анкету, Рівненським інститутом післядипломної педагогічної освіти у квітні 2021 року проведено регіональний моніторинг стану впровадження та рівня матеріально-технічного забезпечення інформаційно-комунікаційних технологій у 33СО, використання цифрових засобів педагогічними працівниками. Це дозволяє порівняти дані двох досліджень.

Актуальність статті полягає у виявленні потреб педагогічних працівників закладів освіти на національному та обласному рівнях, визначенні тенденцій щодо використання цифрових інструментів і ресурсів під час організації дистанційного навчання в умовах карантину. Практична значущість полягає в наданні рекомендацій, що грунтуються на результатах проведеного опитування.

Аналіз наукових досліджень і публікацій. Питання застосування дистанційного навчання в освітньому процесі досліджується в наукових працях В. Бикова, В. Дивака, Н. Думанського, Т. Крамаренко, В. Попова, В. Трохименка та ін.

Дистанційне навчання розглядається як форма організації та реалізації навчального процесу, згідно 3 якою його учасники взаємодіють на відстані, не перебуваючи в одному приміщенні (Биков, 2008, с. 9).

Питання розвитку інформаційно-цифрового середовища в 3ЗСО та застосування цифрових інструментів учителями у порівняльному контексті досліджують
О. Гриценчук, І. Іванюк, Л. Карташова, М. Лещенко, О. Овчарук, I. Пліш, Н. Сороко (Ovcharuk, Ivaniuk, Soroko at al., 2020).

Мета статті - виявити проблеми вчителів у організації дистанційного навчання в умовах карантину на основі вивчення стану використання педагогами цифрових інструментів і онлайн-ресурсів інформаційно-освітнього середовища та надати рекомендації для організації навчання школярів.

Виклад основного матеріалу дослідження. У період із 10 січня 2021 по 10 березня 2021 року співробітниками відділу компаративістики та інформаційно-освітніх інновацій Інституту інформаційних технологій і засобів навчання НАПН України було проведено онлайн-анкетування на всеукраїнському рівні. В опитуванні на добровільних засадах взяли участь 1463 респонденти, серед них - 1298 жінок і 149 чоловіків.

У період із 1 по 20 квітня 2021 року співробітниками Рівненського інституту післядипломної педагогічної освіти був проведений регіональний моніторинг серед керівників, учителів та учнів закладів загальної середньої освіти. Найбільш активними були заклади освіти Рівненської, Рокитнівської, Сарненської, Вараської, Немовицької, Дубровицької, Мізоцької, Зарічненської, Корецької територіальних громад. В опитуванні на добровільних засадах взяли участь 2998 респондентів, серед них - 2686 жінок і 301 чоловік. Опитування було анонімним, усі учасники досліджень були поінформовані щодо цілей дослідження.

Аналіз відповідей респондентів обох досліджень дозволив визначити 10 основних проблем організації та впровадження на практиці дистанційного навчання: недостатнє матеріально-технічне забезпечення учнів; відсутність якісного інтернету; брак часу через збільшення навантаження для вчителя; недостатній рівень матеріально-технічного забезпечення закладів освіти; низький рівень самоорганізованості та мотивації учнів; відсутність підтримки з боку батьків; недостатній рівень цифрової компетентності вчителів; труднощі 3 дистанційним навчанням учнів початкової школи; психологічні труднощі під час дистанційного навчання; зниження рівня якості надання освітніх послуг.

Порівняння основних проблем і викликів, з якими зіткнулися педагогічні працівники під час організації та впровадження дистанційного навчання у 2020 та 2021 роках, свідчить про те, що частина проблем, про які зазначали педагогічні працівники у 2020 році, була успішно вирішена, зокрема: відсутність конкретних інструкцій щодо організації дистанційного навчання від адміністрації 3ЗСО та МОН; недостатність досвіду в учителів з організації дистанційного навчання; недостатність мотивації вчителів щодо здійснення дистанційного навчання.

Проблеми, що існують уже майже рік і залишилися без вирішення, це: недостатнє матеріально-технічне забезпечення учнів; відсутність якісного інтернету; брак часу через збільшення навантаження для вчителя; недостатній рівень матеріально-технічного забезпечення закладів освіти; низький рівень самоорганізованості та мотивації учнів; недостатній рівень цифрової компетентності вчителів. 
3'явилися нові проблеми, пов'язані з труднощами дистанційного навчання учнів початкової школи; психологічні проблеми в усіх учасників освітнього процесу; зниження рівня якості надання освітніх послуг; відсутність підтримки з боку батьків.

Важливим питанням було визначення того, як учасники опитування організовують дистанційне навчання та які засоби використовують для проведення уроків під час дистанційного та змішаного навчання в умовах пандемії COVID-19.

За результатами всеукраїнського опитування було з'ясовано, що для організації дистанційного навчання респонденти найчастіше використовують такі цифрові інструменти: Viber (83\%), Zoom (58,7\%), сайти закладів освіти (58,7\%), МійКлас (20,7\%), Padlet (18,8\%), Google Apps for Education (15,1\%), Skype (14\%), Telegram (13,8\%), Електронний щоденник (11,7\%), навчальні платформи закладів освіти (10\%), Jitsi Meet $(9,5 \%)$.

Також респонденти вказали на використання таких інструментів, як: Tik-Tok, Microsoft Teams, Cisco Webex, ClassDojo, Edmodo, Moodle, Twitter, WhatsApp, проте частка їхнього використання складає не більше $4 \%$

Порівнюючи результати опитувань щодо використання цифрових інструментів для організації дистанційного навчання, проведених нами у 2020 та 2021 роках (див. табл. 1), можемо зробити висновок, що найбільш популярним інструментом серед учителів залишається Viber (83\%) і сайт закладу освіти $(58,7 \%)$. Відповідно збільшилася кількість користувачів Zoom $(+30,2 \%)$, Padlet $(+18,2)$, JitsiMeet $(+8,8 \%)$, CiscoWebex $(+3,3 \%)$, Edmodo $(+3,2 \%)$, однак зменшилася кількість тих, хто використовує Google Apps for Education (30,4\%), Skype (-23,7\%), Telegram $(-7,1 \%)$. Приблизно на однаковому рівні продовжують використовувати МійКлас $(+2,2 \%)$, Microsoft Teams $(-0,7 \%)$, Електронний щоденник $(+1,4 \%)$, ClassDojo (+1,6\%). Варто зауважити, що педагоги почали застосовувати й нові інструменти, зокрема Tik-Tok (+4\%), Twitter $(+4 \%)$.

Результати опитування педагогічних працівників Рівненської області (див. табл. 1) свідчать, що найбільше у своїй роботі респонденти використовують такі цифрові інструменти для організації дистанційного навчання, як: Viber $(89 \%)$, Zoom $(36,4 \%)$, сайт закладу освіти $(33,1 \%)$, МійКлас $(21,7 \%)$, Jitsi Meet (18,8\%), Google Apps for Education (13,8\%), навчальна платформа закладу освіти $(13,6 \%)$, Telegram $(9,8 \%)$, Електронний щоденник $(9,8 \%)$, Skype $(9,1 \%)$, Padlet (5,8\%), Microsoft Teams (4,4\%). Це свідчить про те, що на регіональному рівні, порівняно із всеукраїнським, педагогічні працівники більше використовують Viber, Jitsi Meet, Google Apps for Education та навчальні платформи закладу освіти, а менше - Zoom, Padlet, Skype i Telegram.

Таблиия 1

Використання педагогічними працівниками цифрових інструментів за результатами всеукраїнського опитування у 2020 та 2021 роках та опитування у Рівненській області у 2021 році

\begin{tabular}{|c|c|c|c|}
\hline Інструмент & $\begin{array}{c}\text { Використання } \\
\text { у квітні } 2020 \text { р. } \\
\text { (у \%) }\end{array}$ & $\begin{array}{l}\text { Використання } \\
\text { у січні - лютому } \\
2021 \text { р. (у \%) }\end{array}$ & $\begin{array}{c}\text { Використання } \\
\text { у Рівненській області } \\
\text { у квітні } 2021 \text { р. (у \%) }\end{array}$ \\
\hline Google Apps for Education & 45,5 & 15,1 & 16,7 \\
\hline Zoom & 28,5 & 58,7 & 36,4 \\
\hline Padlet & 0,6 & 18,8 & 5,8 \\
\hline Навчальна платформа закладу освіти & 0 & 10 & 13,6 \\
\hline Twitter & 0 & 4 & 0,7 \\
\hline Edmodo & 0,8 & 4 & 0 \\
\hline Viber & 88,2 & 83 & 89 \\
\hline $\begin{array}{l}\text { Сайт } \\
\text { закладу освіти }\end{array}$ & 62,7 & 58,7 & 33,1 \\
\hline JitsiMeet & 0,7 & 9,5 & 18,8 \\
\hline Tik-Tok & 0 & 4 & 0,8 \\
\hline CiscoWebex & 0,7 & 4 & 0 \\
\hline МійКлас & 18,5 & 20,7 & 21,7 \\
\hline ClassDojo & 2,4 & 4 & 1,3 \\
\hline Електронний щоденник & 10,3 & 11,7 & 9,8 \\
\hline Moodle & 3,4 & 4 & 2,2 \\
\hline Microsoft Teams & 4,7 & 4 & 4,4 \\
\hline Telegram & 20,9 & 13,8 & 9,8 \\
\hline WhatsApp & 13,3 & 4 & 2,5 \\
\hline Skype & 37,7 & 14 & 9,1 \\
\hline
\end{tabular}


Результати всеукраїнського опитування свідчать, що для проведення уроків педагогічні працівники зазвичай використовують: авторські уроки на каналі YouTube (75,8\%), ресурси На Урок $(74,4 \%)$, Всеосвіта $(64,6 \%)$, Всеукраїнська школа онлайн $(38,7 \%)$, EdEra $(33,3 \%)$, а також матеріали блогів учителів $(28,4 \%)$, відкриті онлайн-уроки (27,2\%), Learning.ua (24,7\%), Prometheus (19,85\%). Менш популярними є: Classtime $(7,7 \%)$, Kahoot $(8,1 \%)$, відеоуроки на ТРК «Ера» та місцевих телеканалах $(5,3 \%)$, а також на ТРК «Київ» $(5,3 \%)$ та Цифровій освіті «Дія» $(5,2 \%)$ тощо.

Також педагоги додали до переліку ресурсів: власні блоги, розробки, презентації, електронні підручники, посібники та матеріали для каналу YouTube, однак ці ресурси не набрали більше 1-2\% відповідей, що свідчить про низьку спроможність педагогів створювати їх самостійно.

Якщо порівняти дані двох опитувальників (2020 та 2021 років) щодо використання онлайн-ресурсів для організації дистанційного навчання (див. табл. 2), можемо зробити висновок, що найбільш популярними серед педагогів залишаються авторські уроки на каналі YouTube $(75,8 \%)$. Збільшилася кількість користувачів ресурсів Всеосвіта $(+62,6 \%)$ та На Урок $(+31,7 \%)$. Крім того, респонденти часто використовують матеріали блогів учителів $(+26,4 \%)$, відкриті онлайн-уроки $(+25,2 \%)$, менше - онлайн-курси МОН з підготовки до ЗНО (-27,3\%), відеоуроки на ТРК «Київ» $(-17,5 \%)$, Prometheus (-12,7\%), Цифрова освіта «Дія» (-10,2\%), EdEra (-9\%), відеоуроки на місцевих телеканалах $(-6,5 \%)$. Приблизно на однаковому рівні залишається використання ресурсу Classtime $(+1,5 \%)$. Водночас вчителі почали використовувати й нові онлайн-ресурси, зокрема Всеукраїнську школу онлайн $(+38,7 \%)$, Learning.ua $(+24,7 \%)$, Kahoot $(+8,1 \%)$.

Результати опитування педагогічних працівників Рівненської області щодо використання онлайн-ресурсів (див. табл. 2) свідчать про певне співпадіння 3 результатами всеукраїнського опитування. Однак варто зауважити, що значним попитом серед освітян користуються такі ресурси, як Всеосвіта та Всеукраїнська школа онлайн.

Висновки. Проведені опитування та аналіз отриманих результатів дають підстави зробити певні висновки. Так, зважаючи на проведення в Україні адміністративно-територіальної реформи, що неабияк вплинула на розподіл повноважень і відповідальність місцевих органів влади за функціонування та забезпечення якісної освіти, до питання організації дистанційного навчання учнів в українських школах має бути привернена особлива увага. Зокрема, об'єднані територіальні громади передусім повинні забезпечити належні умови для організації навчання дітей.

Ключову роль у питаннях здійснення дистанційного навчання відведено вчителеві. Саме тому основна увага держави має бути спрямована на всебічне сприяння вчителям у цьому процесі. Як свідчать результати проведеного опитування, не всі педагоги знаходяться у рівних умовах щодо організації та здійснення дистанційного навчання. Попри наявні значні напрацювання на теренах упровадження IКТ в освітній процес, широкий спектр наукових розробок та методичних вказівок щодо того, як саме мають використовуватися цифрові засоби у процесі навчання, питання підняття спроможності та підтримки готовності вчителів до використання IКТ досі на часі.

Таблиия 2

Використання педагогічними працівниками онлайн-ресурсів за результатами всеукраїнського опитування у 2020 та 2021 роках та опитування у Рівненській області у 2021 році

\begin{tabular}{|c|c|c|c|}
\hline Pecypc & $\begin{array}{c}\text { Використання } \\
\text { у квітні 2020 р. } \\
(\mathbf{y} \%) \\
\end{array}$ & $\begin{array}{c}\text { Використання } \\
\text { у січні - лютому } \\
2021 \text { р. (у \%) } \\
\end{array}$ & $\begin{array}{c}\text { Використання } \\
\text { у Рівненській області } \\
\text { у квітні } 2021 \text { р. (у \%) }\end{array}$ \\
\hline Всеосвіта & 2 & 64,6 & 71,5 \\
\hline Всеукраїнська школа онлайн & 0 & 38,7 & 46,1 \\
\hline На Урок & 42,7 & 74,4 & 83 \\
\hline Матеріали блогів учителів & 2 & 28,4 & 24,2 \\
\hline Відкриті онлайн-уроки & 2 & 27,2 & 28,9 \\
\hline Learning.ua & 0 & 24,7 & 16,5 \\
\hline $\begin{array}{l}\text { Авторські уроки на каналі } \\
\text { YouTube }\end{array}$ & 72,9 & 75,8 & 79,3 \\
\hline Classtime & 6,2 & 7,7 & 7,7 \\
\hline Kahoot & 0 & 8,1 & 9,6 \\
\hline $\begin{array}{l}\text { Відеоуроки на місцевих } \\
\text { телеканалах }\end{array}$ & 11,8 & 5,3 & 3,2 \\
\hline EdEra & 42,3 & 33,3 & 32,5 \\
\hline Цифрова освіта «Дія» & 15,4 & 5,2 & 3,7 \\
\hline Prometheus & 32,5 & 19,8 & 15,3 \\
\hline Відеоуроки на ТРК «Київ» & 22,8 & 5,3 & 6,5 \\
\hline
\end{tabular}


Представлені нами у дослідженні результати можуть бути використані:

- урядовими установами, Міністерством освіти і науки України, управліннями освіти на різних рівнях (для розроблення планів дій, програм, проведення заходів, що спрямовані на підтримку вчителів в умовах карантину). Важливу роль у процесі забезпечення освітнього процесу відіграє Міністерство ичифрової трансформачї̈, покликане забезпечувати та контролювати процес оснащення закладів освіти цифровими засобами для організації навчання. Має бути укладена дорожня карта щодо цифровізації закладів освіти, що забезпечить створення планів дій для областей України та об'єднаних громад із цього питання. Крім того, має бути проведений актуальний аналіз поточного стану оснащення шкіл та особисто вчителів з огляду на здійснення дистанційного навчання для учнів. Міністерство соиіальної політики повинно проаналізувати спроможність малозабезпечених сімей у можливостях забезпечення дітей шкільного віку доступом до інтернету та цифрових засобів для навчання, а також сприяти ініціативам громадськості зі збору комп'ютерного обладнання, яке було у використанні та може бути використаним у школах та родинах учнів;

- закладами загальної середньої освіти та іншими освітніми установами (для побудови каналів комунікації, онлайн-підтримки та інформування колективів щодо планів роботи, наявних технічних та програмних засобів, можливостей для учнів та батьків в умовах конкретного регіону та закладу освіти, швидкого реагування на потреби вчителів та учнів, підтримки вчительських інновацій);

- закладами післядипломної педагогічної освіти та іншими установами, що здійснюють підвищення кваліфікації вчителів (для запровадження та методичного супроводу онлайн-заходів із підвищення кваліфікації вчителів, зокрема щодо використання IКТ та проведення дистанційного навчання, інформування про нові онлайн-можливості для вчителів, консультування їх щодо здійснення дистанційного навчання), створення «гарячих ліній» для консультування вчителів із питань використання IКТ та вирішення проблем у цій сфері, адже в штатному розкладі З3СО відсутня посада працівника 3 надання технічної підтримки дистанційного навчання;

- науково-дослідними установами, зокрема в системі НАПН України (для розроблення інструментів та методик підтримки онлайн-навчання з різних предметних галузей, виявлення прогалин та пропонування інноваційних, ефективних науково обгрунтованих онлайн-засобів та науково-методичного супроводу, що забезпечать учителів і систему підвищення кваліфікації новітніми розробками); важливим є створення нових цифрових платформ із доступними онлайн-ресурсами для вчителів усіх предметів та покроковими інструкціями щодо їхнього використання;

- іншими зацікавленими сторонами, зокрема організаціями громадянського суспільства (для підтримки онлайн-навчання в умовах карантину, моніторингу й оцінювання рівня доступу до освітніх послуг і процесу дотримання прав учнів на освіту в умовах карантину та обмежень, що спричинені цим). Залучення освітнього омбудсмена до питань дотримання права учнів на якісну освіту та належних умов праці вчителів, проведення консультацій із цим представництвом та розроблення планів моніторингу дотримання таких прав;

- органами влади щодо розробки та запровадження державних програм грантової підтримки громадських ініціатив подолання викликів, що постали перед учителями у процесі запровадження дистанційного навчання.

Перспективи подалыших досліджень. Проведене дослідження не вичерпує вирішення всього спектра проблем, пов'язаних із готовністю вчителів до організації дистанційного навчання. У зв'язку з цим плануємо продовжити науковий пошук щодо використання вчителями різних предметів цифрових засобів навчання, створення інформаційно-цифрового середовища закладів освіти, зокрема й післядипломної, оцінювання готовності закладів освіти до здійснення дистанційного навчання на регіональних рівнях.

\section{СПИСОК ВИКОРИСТАНОЇ ЛІТЕРАТУРИ}

OECD. (2020). Education responses to COVID-19: Embracing digital learning and online collaboration. URL: https://oecd.dam-broadcast.com/pm_7379_120_1205448ksud7oaj2.pdf (Accessed: 30.05.202 $\overline{1}$ ).

The Council of Europe. (2020). COVID-19 Response. URL: https://www.coe.int/en/web/education/covid-19 (Accessed: 30.05.2021).

Іванюк, І. В., Овчарук, О. В. (2021). Результати онлайн-опитування. Готовність і потреби вчителів щодо використання цифрових засобів та IКТ в умовах карантину: 2021. Аналітичний звіт. Київ: IІТЗН НАПН України. URL: https://lib.iitta.gov.ua/724564 (дата звернення: 30.05.2021).

Іванюк, І. В., Овчарук, О. В. (2020). Стан готовності педагогів $33 \mathrm{CO}$ до застосування інформаційно-освітнього середовища для здійснення дистанційного навчання в умовах карантину, спричиненого COVID-19. Нова педагогічна думка. № 3 (103). С. 48-54.

Ivaniuk, I., Ovcharuk, O. (2020). The response of Ukrainian teachers to COVID-19: challenges and needs in the use of digital tools for distance learning. Informational Technologies and Learning Tools. T. 77. No. 3. Pp. 282-291. URL: https://doi.org/10.33407/itlt.v77i3.3952 (Accessed: 30.05.2021).

Ovcharuk, O., Ivaniuk, I., Soroko, N., Gritsenchuk, O., Kravchyna, O. (2020). The use of digital learning tools in the teachers' professional activities to ensure sustainable development and democratization of education in European countries. E3S Web of Conferences. 166 (10019). URL: https://www.e3s-conferences.org/articles/e 3 sconf/ $\mathrm{abs} / 2020 / 26 / \mathrm{e} 3 \mathrm{sconf}$ icsf2020 10019/e $3 \mathrm{sconf}$ icsf2020_10019.html (Accessed: 30.05.2021).

Биков, В. Ю. та ін. (2008). Технологія створення дистанційного курсу. Київ: Міленіум. 324 с.

\section{REFERENCES}

OECD. (2020). Education responses to COVID-19: Embracing digital learning and online collaboration. URL: https://oecd.dam-broadcast.com/pm_7379_120_1205448ksud7oaj2.pdf (Accessed: 30.05.2021). [in English].

The Council of Europe. (2020). COVID-19 Response. URL: https://www.coe.int/en/web/education/covid-19 (Accessed: 30.05.2021). [in English]. 
Ivaniuk, I. V., Ovcharuk, O. V. (2021). Rezultaty onlain-opytuvannia. Hotovnist i potreby vchyteliv shchodo vykorystannia tsyfrovykh zasobiv ta IKT v umovakh karantynu: 2021. Analitychnyi zvit. [The results of an online survey of teachers' readiness and needs for the use of digital tools and ICT in quarantine: 2021. Analytical report]. Kyiv: IITZN NAPN Ukrainy. URL: https://lib.iitta.gov.ua/724564 (data zvernennia: 30.05.2021). [in Ukrainian].

Ivaniuk, I. V., Ovcharuk, O. V. (2020). Stan hotovnosti pedahohiv ZZSO do zastosuvannia informatsiino-osvitnoho seredovyshcha dlia zdiisnennia dystantsiinoho navchannia v umovakh karantynu, sprychynenoho COVID-19 [The state of readiness of teachers of Secondary Schools to use the information and educational environment for the implementation of distance learning in quarantine caused by COVID-19]. Nova pedahohichna dumka. № 3 (103). S. 48-54. [in Ukrainian].
Ivaniuk, I., Ovcharuk, O. (2020). The response of Ukrainian teachers to COVID-19: challenges and needs in the use of digital tools for distance learning. Informational Technologies and Learning Tools. T. 77. № 3. Pp. 282-291. URL: https://doi.org/10.33407/itlt.v77i3.3952 (Accessed: 30.05.2021). [in English].

Ovcharuk, O., Ivaniuk, I., Soroko, N., Gritsenchuk, O. \& Kravchyna, O. (2020). The use of digital learning tools in the teachers' professional activities to ensure sustainable development and democratization of education in European countries. E3S Web of Conferences. 166 (10019). URL: https://www.e3s-conferences.org/articles/e3sconf/ abs/2020/26/e 3sconf_icsf2020 10019/e 3sconf icsf2020 10019.html (Accessed: 30.05.2021). [in English].

Bykov, V. Yu. ta in. (2008). Tekhnolohiia stvorennia dystantsiinoho kursu [Technology of creating a distance course]. Kyiv: Milenium. 324 s. [in Ukrainian].

Дата надходження до редакиії: 16.09.2021 p.

\section{Неля КIHAX,}

кандидат економічних наук, доиент кафедри педагогіки та психології Волинського інституту післядипломної педагогічної освіти, м. Луцьк, Украӥна ORCID: 0000-0002-9025-6514 e-mail:nelyakinax@gmail.com

Наталія РУБЛЬОВА, заступник директора з проєктної діяльності та платних послуг

Волинського інституту післядипломноі педагогічної освіти,

м. Луцьк, Украӥна

ORCID: 0000-0001-8341-7095

e-mail:n.rublova@vippo.org.ua

\section{ПІДВИЩЕННЯ ФАХОВОГО РІВНЯ ВЧИТЕЛІВ ПОЧАТКОВОЇ ШКОЛИ У КОНТЕКСТІ ЦИФРОВОГО ПІДПРИЕМНИЦТВА}

\begin{abstract}
Анотація. У статті досліджено особливості навчання вчителів початкової иколи цифровому підприсмнииттву з метою підвищення їх фахового рівня, шуо зумовлено иифровізацією освітнього середовища, яке вимагає від вчителя нових професійних знань та вмінь, аналізу методів та прийомів роботи з молодшими школярами. Зміст цифрової компетентності обтрунтовано з урахуванням критичного й відповідального використання ичиррових технологій та взаємодії з ними впродовж навчання, професійної діяльності та життя у складних умовах сьогодення. Окреслено ключові завдання щзодо навчання циифровому підприємництву, котрі передбачають: створення новітніх освітніх иифрових продуктів, бізнес-практик, інформаційних ресурсів із ведення ичифрового підприємництва; розробку нової якості ичифрових навчальних
\end{abstract}

ресурсів з урахуванням особливостей стилів сприйняття матеріалу та рівня професійного розвитку, трансформації, модернізаиії й адаптації підприємництвв в умовах мінливого освітнього середовита. Визначено результати навчання ичифровому підприємництву, щзо формують нову якість компетениій учителів початкової школи з метою набуття ичиррових навиків підприємництва, оволодіння новітніми цчифровими інструментами, щзо використовуються в ході навчання циирровому підприємництву з метою становлення нової якості співпрачі та комунікаиії, та новітніми технологіями е-навчання в умовах віртуальної реальності.

Ключові слова: иифрова компетентність, иифровізація, ичифрове підприємництво, циифрові технології, иифрова освіта. 